\title{
Integrated methodologies for flood risk management practice in European pilot sites
}

J. Schanze, P. Bakonyi, M. Borga, B. Gouldby, M. Marchand, J.A. Jiménez \& H. Sterr

Reproduced from:

Flood Risk Management - Research and Practice Proceedings of FLOODrisk 2008

Keble College, 0xford, UK

30 September to 2 October 2008 


\title{
Integrated methodologies for flood risk management practice in European pilot sites
}

\author{
J. Schanze \\ Leibniz-Institut für ökologische Raumentwicklung e.V., Dresden, Germany \\ P. Bakonyi \\ Water Resources Research Centre (VITUKI), Budapest, Hungary \\ M. Borga \\ University of Padova, AGRIPOLIS, Legnaro, Italy \\ B. Gouldby \\ HR Wallingford, Wallingford, UK
}

M. Marchand

Deltares, Delft, The Netherlands

J.A. Jiménez

Universitat Politécnica de Catalunya, Barcelona, Spain

H. Sterr

Geographisches Institut UAG Küstengeographie \& Naturgefahren, Universität Kiel, Kiel, Germany

Flood risk management is a societal challenge: It encompasses the analysis of risk generation in complex human-environment systems, the evaluation of the tolerability of risk as well as the design and implementation of risk reduction measures. Multiple actors are involved in the process of collecting information, decision making and acting. Science may support this endeavour by specific natural and social science investigations and software tool developments. The complex levels of flood risk management, however, require a comprehensive understanding of the entire issues and special methodologies for the emergent tasks.

The paper presents results from developing and testing integrated methodologies to support flood risk management in European pilot sites of the FLOODsite project. Based on a conceptual framework of the societal flood risk management it illustrates how significant advances can be made by context-specific integrated approaches. The framework describes flood risk management from the perspective of multiple decision makers and experts who are responsible for dealing with flood risk as a real-world problem and related management tasks. Moreover, it explicates the management process itself considering the context and process dimension in addition to the contents.

Following this framework, integrated methodologies and their contributions to flood risk management practice are shown from seven European pilot sites, the Elbe River basin, a network of European flash flood basins, the Tisza River basin, the Thames River estuary, the Scheldt River estuary, the Ebro River Delta coast and the German Bight coast. With respect to the first task of risk management, which is risk analysis, it is shown how coupled modelling of flood hazards and flood vulnerabilities can improve the societal understanding of riverine, estuarine and coastal flood risk systems and their dynamic. Major features of the different approaches are detailed, as well as, their potential role in supporting the implementation of the Floods Directive.

For the second task of risk management, risk evaluation, an overview is given on findings regarding appropriate criteria and methods. This covers both the ex post and ex ante risk evaluation of the flood risk system. It also deals with the performance of risk reductions options, which links to the third task of risk management. In this respect, the meaning of certain physical measures and policy instruments for the pilot sites is explained and possible improvements for selected measures are derived. 
For the interface between these three tasks and the flood risk management process, decision support tools play an increasing role. Different software tools have been developed and applied at three pilot sites. Principle differences between these tools are explained and briefly discussed in the light of their functionality and societal applicability. Based on this, results from site-specific investigations on risk perception, strategic planning and stakeholder involvement lead to the initial presumption that science needs also to address the social challenge of flood risk management. Investigations suggest significant differences between the requirements of the various actors of flood risk management and the people at risk. Final conclusions are thus drawn, with respect to the future elaboration of flood risk management plans and public involvement according to the Floods Directive.

Keywords: Flood risk management, methodologies, risk analysis, risk evaluation, risk reduction, pilot sites 


\title{
Fluid thinking...smart solutions
}

HR Wallingford provides world-leading analysis, advice and support in engineering and environmental hydraulics, and in the management of water and the water environment. Created as the Hydraulics Research Station of the UK Government in 1947, the Company became a private entity in 1982, and has since operated as a independent, non profit distributing firm committed to building knowledge and solving problems, expertly and appropriately.

Today, HR Wallingford has a 50 year track record of achievement in applied research and consultancy, and a unique mix of know-how, assets and facilities, including state of the art physical modelling laboratories, a full range of computational modelling tools, and above all, expert staff with world-renowned skills and experience.

The Company has a pedigree of excellence and a tradition of innovation, which it sustains by re-investing profits from operations into programmes of strategic research and development designed to keep it - and its clients and partners - at the leading edge.

Headquartered in the UK, HR Wallingford reaches clients and partners globally through a network of offices, agents and alliances around the world.

\section{HR Wallingford}

Working with water

\author{
HR Wallingford Ltd \\ Howbery Park \\ Wallingford \\ 0xfordshire 0X10 8BA \\ UK
tel $\quad+44(0) 1491835381$
fax +44 (0)1491832233
email info@hrwallingford.co.uk

\section{www.hrwallingford.co.uk}

